\title{
OS ESCRITORES NOS DIÁRIOS
}

\author{
J. Esteves Rei
}

Universidade de Trás-os-Montes e Alto Douro (UTAD)

\section{PRESSUPOSTOS}

1.1 Escritores e diários desempenham uma função psicagógica - Ambos aspiram à condução das massas numa sociedade laica ou laicizada, depois da revolução liberal. Quer dizer, tanto uns como outros têm, no horizonte, um público leitor hipotético constituído pelo universo de concidadãos falantes e letrados da sua língua. Mais, a sua função ou missão decorre de uma necessidade, individual e colectiva, de orientação das massas populares que, após a queda do antigo regime e com a laicização do regime liberal, se viram sem orientação axiológica, ética e moral, mas também, sociológica, política, filosófica, cultural ou, simplesmente, humanística.

Nesta função, escritores e diários disputam o seu espaço social com outros poderes. No caso dos diários vêem-no aumentar, com a consequente cedência de poderes como o político, o judicial e até o económico. Assim o reconhecia o sociólogo António Barreto, em entrevista ao Público, a 1 de Novembro:

[...] os jornalistas [...] têm imposto sucessivas exigências à vida política e os políticos têm cedido sempre. A começar por recrutarem jornalistas para o seu gabinete julgando que assim influenciam melhor o que sai nos noticiários. Os políticos têm cedido mais aos jornalistas $[\ldots]$ do que o contrário. ${ }^{1}$

Os escritores não dão provas de tal sucesso, como o expressa Miguel Torga:

As minhas relações com os governantes hão-de ser sempre uma relação crispada. Mesma quando uma real simpatia nos aproxima o diálogo nunca é naturalmente cordial. Há nele, subjacente, não sei que mútua reticência. [...] o político [...] tem qualquer coisa de pre- 
dador humano. [...] Quero abrir-lhe o coração e não consigo. [...] só um objectivo o move na vida: o poder. Que por ele de tudo é capaz, diga o que disser, pareça o que pareça. Nesse desejo obstinado de mando, de domínio, vejo, não sei porquê comprometida a minha liberdade. ${ }^{2}$

$1.2 \mathrm{O}$ povo povo, na expressão de Almeida Garrett ${ }^{3}$, ou a burguesia, diríamos nós hoje, é um leitor ou consumidor de escritas e escritos, quer de obras quer de diários. Partilhando a mesma função ou missão, escritores e jornais dirigem-se a esse povo, leitor e consumidor de uma realidade nova, o escrito / a escrita, desses actores sociais emergentes, os escritores e os diários.

Thibaudet dá-nos notícia do que representou a imprensa em 1789, prenúncio do papel que viria a desempenhar em todo o século XIX, em ligação com a literatura, e no século xx, até hoje, tendo-se dela aparentemente divorciado:

O povo lê. Lê sobretudo jornais. Os jornais são seguramente a parte mais viva da literatura revolucionária. São-no desde os Estados Gerais de 1789, que se reuniam já levados por uma curiosa literatura espontânea a dos «Cadernos», redigidos nas pequenas cidades e nos campos, por procuradores, professores primários, párocos, e nos quais não faltam os acentos pitorescos e singulares, sinceros e pungentes. ${ }^{4}$

1.3 A presença dos escritores nos diários é mal vista nos ensinos universitário e secundário, de um modo geral e em abstracto, em especial, pela Universidade ou pelos universitários que

2. Miguel Torga, Diário (IX-XVI), Coimbra, 1995, pp. 1585-1586. Sobre o mesmo tema poderá consultar-se a posição de Vergílio Ferreira, em Conta Corrente 2, 1977 -1979, Lisboa, Bertrand, 1981, p. 207.

3. Almeida Garrett, Viagens na Minha Terra, «Mas ainda espero melhor todavia, porque o povo, o povo povo, está são; os corruptos somos nós, os que cuidamos saber e ignoramos tudo.», in http://www.bibvirt.futuro.usp.br/textos/autores/almeidagarret/ viagensnaminhaterra/viagens_texto.html.

4. Thibaudet, Histoire de la littérature Française, apud, Dalcídio Jurandir, «Eça de Queiróz, repórter», in Livro do Centenário de Eça de Queiroz, Lúcia Miguel Pereira e Câmara Reys (orgs.), Lisboa e Rio, Edições dois Mundos, Livros do Brasil e Livros de Portugal, 1945, p. 207. 
tratam dos escritores e suas obras - Aparentemente, a razão verbalizada dessa indisposição perante a presença dos escritores nos diários é a deficiente relação que os jornais mantêm quer com o pensamento e a cultura quer com a língua ou a distância desta linguagem jornalística com a norma cuidada ou literária. A verdadeira razão, porém, poderá não estar aí e andar, por exemplo, por uma disputa do espaço da crítica literária, o que terá acabado por conduzir a duas críticas (literárias): a universitária e a jornalística. Essa questão, da língua literária e da língua jornalística, parece ainda hoje não estar completamente debelada nem por literatos, nem por lingüistas, nem por jornalistas. Houve, porém, momentos em que ela foi particularmente sentida e verbalizada:

a) Desde a segunda metade do século XIX que E. M. Campagne, no seu Dicionário Universal de Educação e Ensino ${ }^{5}$, afirma:

Nestes tempos que vão correndo, o jornal usurpou ao livro o maior de todos os valores [...] o tempo; [...]. Amanhã, o jornal absorve-nos também o espaço. [...] o jornal [tornou-se] uma das mais características feições do nosso tempo.

b) Dele encontramos as piores referências em intelectuais da estatura dos Professores João da Silva Correia e Manuel de Paiva Boléo, nas décadas de 20 e 50, respectivamente. Para o primeiro, na peugada de Eça, o jornal concorre para que «se aligeirem mais os Juízos ligeiros, se exacerbe a Vaidade, e se endureça mais a Intolerância». O segundo destaca o conflito, no jornal, entre o cronista crítico e o editor de um escritor, quando afirma:

A crítica artística fenece sob o peso esmagador do reclame. De nada serve que um cronista de boas letras faça no rodapé de uma gazeta a apreciação de um trabalho literário, romance ou peça dramática, se mesmo por cima das suas linhas de meditada exegese um cartaz de livreiro editor ou de empresário de teatro diz que a obra

5. E. M. Campagne, Dicionário Universal de Educação e Ensino, trad. Camilo Castelo Branco, Porto e Braga, Liv. Internacional Ernesto Chardon e Eugénio Chardon, 1873. 
que o crítico acha justa e sabiamente uma vergonha da literatura - é a mais colossal, fenomenal e sensacional produção estética do seu tempo. ${ }^{6}$

A opinião de Paiva Boléo sobre a função cultural do jornal não é mais positiva, ao afirmar, também ele, que

a nossa época febril, agitada, cheia de apreensões sobre o futuro, é hostil à verdadeira cultura. (O jornal, a revista ilustrada, a novela policial e o cinema satisfazem plenamente as necessidades intelectuais de muita gente ...) Ao vermos que uma parte da mocidade só se entusiasma pelo futebol, temos saudades daquela simpática curiosidade intelectual [...], do tempo de Antero e Eça de Queirós. ${ }^{7}$

c) Também a escola secundária manteve (não manterá mais?) esta visão negativa do jornal, como registamos no manual mais utilizado na primeira metade do século $\mathrm{XX}^{8}$, $\mathrm{O}$ do jesuíta Jules Verest ${ }^{9}$, que define o jornal como «o portavoz dos homens e das associações políticas $»^{10}$ e o artigo de fundo como «a parte essencial, doutrinal [consistindo em] lembrar, a propósito dos factos do dia, os princípios que é necessário inculcar nos leitores, ilustrando assim o abstracto pelo concreto». Caracteriza, ainda, o poder do jornal como «formidável, para o bem e para o mal, desde que ele tenha redactores eloquentes e hábeis [...]. O jornal causou e causa ainda males inumeráveis». E enumera: 1) torna-se o veículo do erro e intoxica as inteligências; 2) desvia das

6. João da Silva Correia, Educação do Pensar Imaginativo e do Pensar Lógico, Coimbra, Imprensa da Universidade, 1924, p. 11.

7. Manuel de Paiva Boléo, Para um maior rendimento do trabalho intelectual, Coimbra, Edição do Autor, 1952, p. 17.

8. Tendo, na nossa opinião, estado na origem de outros manuais como o de Abel Guerra, Elementos de Composição Literária (Ensino Secundário, Porto, Livraria Apostolado da Imprensa, 1966, $6^{\text {a }}$ ed.), que, nas páginas 205 e 206, cita esse manual de Jules Verest, a seguir referenciado. Cf. José Esteves Rei, A Escola e o Ensino das Linguas, Porto, Porto Editora, 1998, pp. 83-84.

9. Jules Verest, Manuel de Littérature. Principes - Faits Généraux - Lois, Bruxelles, Desclée, De Brouwer, Bruges, 1939, 14e ed.

10. Ibid., p. 569. 
leituras sérias e do estudo; 3) deprime a inteligência e torna-a incapaz de um esforço.

2 DOS TERMOS E SUA COMPREENSÃO: ESCRITORES

E DIÁRIOS

2.1 O escritor - Deixemos de lado o caso de Cícero - o primeiro escritor, avant la lettre, por um amigo seu, apaixonado pela leitura de discursos forenses, lhe publicar esses discursos, depois de refeitos, e os seus contemporâneos sentirem prazer na mesma leitura. Deixemos de parte, ainda, o caso semelhante do Padre António Vieira - a quem o apostolado colocava idêntica exigência de publicação dos seus sermões, também eles refeitos fora do púlpito. Fixemo-nos, sim, no escritor romântico, poeta e literato, que descobre e recebe uma função, assim definida por Victor Hugo:

O poeta [...] / Vem preparar dias melhores / Ele é o homem das utopias / [...] / É ele que sobre todas as frontes / [...] / faz resplandecer o futuro. [...] Os seus sonhos [...] / São feitos das sombras que lhe lançam / as coisas que virão um dia. ${ }^{11}$

E o narrador aconselha para a salvação possível:

Povos! Escutai o poeta! / Escutai o sonhador sagrado / Na vossa noite sem ele completa / [...] Deus fala em voz baixa à sua alma / [... / Ele reina! Ele lança a sua chama / Sobre a verdade eterna! [...] / Pois a poesia é a estrela / Que conduz a Deus reis e pastores.

Entre nós, é Almeida Garrett que melhor assimila e expressa esta função do escritor:

Coligir os factos do homem [é], emprego para o sábio; [...] achar a lei de suas séries, ocupação para o filósofo e o político; [...] derramar pelas nações um ensino fácil, uma instrução intelectual e moral que, sem aparato de sermão ou de prelecção, surpreenda os

11. Victor Hugo, «Fonction du poète», in Littérature Française, XIX siècle, Lagarde et Michard, p. 162. 
ânimos e os corações da multidão no meio dos seus próprios passatempos [é] a missão do literato e do poeta. ${ }^{12}$

E o introdutor do Romantismo em Portugal remata salientando o compromisso cívico de qualquer tipo de discurso:

Os poetas fizeram-se cidadãos, tomaram parte na coisa pública como sua; querem ir como Eurípedes e Sófocles solicitar na praça os sufrágios populares [...]. Os leitores [...] de hoje querem [...] verdade. Dai-lhe a verdade do passado no romance e no drama histórico; no drama e na novela da actualidade, oferecei-lhe o espelho em que se mire a si e ao seu tempo.

Quer o autor dizer: é pela obra literária e pelo jornal que se forma e se informa o povo.

Também Miguel Torga afina pelo mesmo diapasão quando afirma: «[...] como escritor, reajo contra os tartufos sãos e gordos que fazem da arte um meio para atingirem inconfessados e sujos fins. $\gg^{13}$

Não gostaríamos de surpreender ninguém com este suporte romântico da literatura e do jornalismo. Nesse sentido, lembramos que historiadores da Literatura como Óscar Lotes e Antonino José Saraiva trazem até aos nossos dias a época que denominam, precisamente, de romântica ${ }^{14}$, sublinhando deste modo a unidade cultural que atravessa estes quase duzentos anos.

2.2 Os (jornais) diários - Este ponto é, porventura, aquele que menos relevância deveria merecer neste nosso tratamento do tema, por a maioria dos presentes ter provavelmente recebido nele formação específica. Todavia, gostaríamos de sublinhar a aproximação entre a função do escritor e a dos jornais diários, com seus jornalistas, sentida e expressa em vários momentos e por vários autores.

12. Em Memória do Conservatório Real, cf. João de Barros e Guerreiro Murta, Como se devem ler os Escritores Modernos, Lisboa, Liv. Sá da Costa, s/d, p. 26 e seguintes.

13. Miguel Torga, Diário II, Coimbra, Edição do autor, 1977, 4ª ed.

14. António José Saraiva e Óscar Lopes, História da Literatura Portuguesa, Porto, Porto Editora, 1976, $9^{\text {a }}$ ed. 
Eça de Queiroz, na introdução a Uma Campanha Alegre, na qual reúne a sua participação no «panfleto periódico que se intitulou As Farpas (início em 1871) $»^{15}$, escreve:

E desde então, à ilharga de Ramalho Ortigão, não cessei durante dois anos de arremessar farpas [...] E assim desses tempos ardentes me ficara a ideia duma campanha alegre, muito elevada, em que a ironia se punha radiantemente ao serviço da justiça [...], da demolição de tudo ressaltava uma educação para todos [s.n.].

Neste sentido vai também a tese de J. M. Tengarrinha ${ }^{16}$ quando ao sublinhar que

O [jornal] torna-se a grande porta que permite aos cidadãos leitores e ouvintes entrar pela Assembleia dentro. O [jornal] torna-se a extensão natural do orador parlamentar. Os discursos deste são lidos, são interpretados, em cima de cadeiras, com fervor idêntico ao seu nos solares, nos clubes e nos cafés.

É esta proximidade da função dos jornais com a dos escritores que, na década de 60, leva Tengarrinha a lamentar-se que entre nós as histórias da literatura não tenham ainda dedicado um capítulo às produções jornalísticas.

Por via indirecta também Miguel Torga, em 8 de Julho de 1992, no Estoril, sublinha a aproximação da função dos escritores e dos jornalistas, ao agradecer, nos termos seguintes, o prémio Figura do Ano, atribuído pelos correspondentes da imprensa estrangeira:

Corri também, desde a meninice, as sete partidas. Presenciei, alanceado, cenas cruentas de guerra, contemplei, atónito e envergonhado, os destroços de civilizações criminosamente destruídos, ouvi vociferações de energúmenos a anunciar a multidões fanatizadas o aniquilamento de colectividades inteiras, comunguei com

15. António José Saraiva, Iniciação na Literatura Portuguesa, Lisboa, Gradiva, 1994, p. 127.

16. José Tengarrinha, História da Imprensa Periódica Portuguesa, Lisboa Portugália Editora, 1965, pp. 73-76. 
naturais doutras raças e culturas no mesmo sonho de um futuro próximo de harmonia humana. E dei, com o engenho que pude e algum risco, testemunho empenhado mas descomprometido dessas andanças. Sou, afinal, como vós e à minha medida, o repórter inquieto dum quotidiano sem fronteiras. Nenhum acontecimento significativo sucedido ao longo de quase um século me deixou indiferente e sem um comentário alertador [s.n.]. Fui uma espécie de homem da telegrafia no barco acossado pelas ondas enfurecidas da realidade coetânea a lançar SOSs de aflição. ${ }^{17}$

2.3 Os escritores nos diários - Como compreenderemos a expressão na sua totalidade? Entre outras, nas seguintes direcções:

2.3.1 Na expressão, os escritores podemos vê-los:

a) como actores: seja enquanto artistas, por exemplo, escrevendo, antes, romances, e agora, contos ou cronics, seja enquanto críticos literários e, até, jornalistas, ascendo por vezes à direcção de diários;

b) como tema ou objecto do dito / escrito: pela divulgação de obras e sua(s) teoria(s), da conquista de prémios ou da atribuição de reconhecimento artístico;

c) como cidadãos: desde logo, pelo silêncio imposto, pela presença silenciada, pela ausência censurada; em seguida, pela intervenção cívica, perante situações, factos e pessoas que os levam a sucessivos j'accuse, quais Zolas dispersos no tempo; por último, pela notícia da sua morte, podendo o relevo que lhe é dado ser uma espécie de medida do seu re-conhecimento detido perante o jornal e o publico.

2.3.2 Nessa expressão, os diários - podemos olhá-los:

a) como estando à disposição do escritor, seja em termos pessoais seja em termos colectivos ou institucionais - 
há escritores que têm uma vida de colaboração individual com diários, Vitorino Menésio ${ }^{18}$, enquanto que outros a realizam por militância ou tarefa decorrente de um grupo colectivo, José Saramago ${ }^{19}$;

b) como solicitando uma colaboração entre ambos, diário e escritor, parecendo ser a situação mais natural;

c) como pedindo um serviço do escritor, por vezes, olhando-o como determinante para a sua manutenção e/ou sobrevivência, Agustina Bessa Luís, no Primeiro de Janeiro. ${ }^{20}$

\section{DAS RELAÇÕES ENTRE OS AGENTES: ESCRITORES}

E DIÁRIOS

\subsection{Escritores e diários - aliados}

3.1.1 Três momentos: nas origens - A aliança entre os dois agentes nasce, no século XIX, da proximidade ou intersecção de suas funções e públicos. A esse propósito diria Castilho, logo em 1841, no programa da Revista Universal Lisbonense:

Este século [...] matou a Livraria e pôs no seu lugar o Jornalismo. Assim devia ser porque este século é popular. Os livros eram a muita ciência para poucos homens; os jornais são um pouco de ciência para todos. [...]. Todavia, como afirma Maria de Lourdes Santos, as publicações periódicas [...] serviam igualmente para o lançamento e reconhecimento de autores $[\ldots]_{.}^{21}$

Quanto ao romance folhetinesco e o folhetim-crónica, eles representavam para os jornais

18. José Martins Garcia, Vitorino Nemésio, Lisboa, Vega, 1988, p. 34: «Cirandando pela actividade jornalística, nunca perderá o hábito [...] de enviar artigos, ensaios, crónicas, para os mais diversos órgãos de comunicação social».

19. Na sua passagem, como Director, pelo Diário de Lisboa.

20. Agustina Bessa Luís chegou a ocupar a direcção deste jornal, numa altura em que ele estava já numa fase de grande declínio, em relação ao lugar cimeiro que ocupara entre a imprensa portuguesa até aos anos 60 .

21. Maria de Lourdes Costa Lima dos Santos, Intelectuais Portugueses na Primeira Metade de Oitocentos, Lisboa, Presença, 1988, p. 165. 
um dos principais meios de aliciamento de um público que se pretendia alargado [...] e impunham aos escritores novas sujeições, quer quanto à qualidade quer quanto à quantidade da sua produção, sobretudo através as exigências dos directores dos jornais que, face ao teor das cartas enviadas pelos leitores, incitavam os romancistas a modificar um certo modelo de narrativa e de personagem. ${ }^{22}$

3.1.2 Ao longo do século xx, impuseram-se as páginas literárias, semanais, nos jornais diários, como a forma mais conseguida de aliança entre escritores e diários. Tais espaços viviam da colaboração de críticos, escritores-críticos e leitores que entre si partilhavam pontos de vista, opiniões e investigações a que iam chegando. Quantas contribuições insignes não viram a luz do dia em páginas dos jornais diários: de José Régio a António José Saraiva, de Vergílio Ferreira a Óscar Lopes?

Recordamos uma de António José Saraiva, no Comércio do Porto, a 28 de Junho de 1960, intitulada «As duas literaturas portuguesas». Afirmava:

A literatura portuguesa moderna começa em meados do século XVIII com a prosa de Verney. [Da anterior] é outra a sua temática, outro o seu estilo. [...] Todo esse mundo estilístico e temático aparece desfeito no século XVIII . Dir-se-ia que os escritores deixaram de saber escrever; perderam o sentido da economia dos recursos estilísticos; [...] são demasiado terra-a-terra, roçando pela brutalidade ou demasiado afectados. [...] Além disso deixou de haver padrões comuns; cada escritor é um país diferente. [...] É a partir do século XVIII que os centros regionais como Porto, Coimbra e Baia começam a ganhar importância na literatura. ${ }^{23}$

3.1.3 Desaparecida a página literária dos diários, com a diminuição do espaço ocupado pela literatura (ou a história da literatura, enquanto limiar da cultura escolar ou escolarizada) na sociedade, permanece a crónica, crescendo de importância para jornais, leitores e cronistas. Na ausência de uma história da cró-

22. Maria de Lourdes Costa Lima dos Santos, op. cit., p. 174.

23. António José Saraiva, «As duas literaturas portuguesas», Comércio do Porto, 28, 1960 , p. 6. 
nica no século xx português, socorremo-nos do trabalho de Fernando Venâncio, Crónica Jornalística. Século xx, Antologia, com um prefácio «Ao Leitor», onde se arrumam as 100 crónicas aí presentes, através de categorias que o autor estabelece e desenvolve.

A crónica política não está, entre nós, particularmente desenvolvida, devido ao consulado salazarista - encontrando em Augusto de Castro uma agradável pena e em José Carlos de Vasconcelos e Fernando Assis Pacheco, críticos acérrimos da polícia. Esse meio século é, porém, antecedido e seguido por dois períodos brilhantes, os vinte e cinco anos anteriores à ditadura e os vinte e cinco anos posteriores à mesma. No primeiro, encontramos «o destemido Brito Camacho, o esclarecido Pinheiro Chagas e o distinto Raul Proença». No segundo, surgem «as pungentes intervenções de António José Saraiva e de Vera Lagoa, dois desiludidos da revolução, e as de Artur Portela Filho e Augusto Abelaira, seus lúcidos críticos $[\ldots] . »^{24}$

O episódio quotidiano é o tema de muitas outras crónicas, em jeito de «cenas arrancadas à vida» nas quais o cronista entra como observador ou como personagem. No início do século, surgem-nos vultos como António Boto, Irene Lisboa e Luísa Dacosta. Por vezes tal episódio redunda em autêntica «história», burlesca ou dramática, atingindo elevada densidade discursiva, como acontece na pena de Jaime Cortesão, Maria Ondina Braga e José Cardoso Pires ${ }^{25}$.

A crónica cultural é mais selecta, indo: do apontamento sério e responsável de João de Barros, ao estilo festivo e pândego de Luiz Pacheco e Mário Cláudio; da dureza de José Régio à afabilidade de António Mega Ferreira e à violência de uma Clara Pinto Correia. No caso mais específico de escritores-cronistas, regista Venâncio os casos: da malícia de António Ferro, do espanto de Abel Barros Baptista, da galhofa de José Viale Moutinho e da evo-

24. Fernando Venâncio, Crónica Jornalística. Século xx, Antologia, Braga, Círculo de Leitores, 2004, p. 6.

25. Fernando Venâncio, op. cit., p. 7. 
cação-homenagem de amigos ou mestres literários, como acontece com José Rodrigues Miguéis, referindo-se a Guerra Junqueiro, e Vasco Graça Moura a propósito de David Mourão Ferreira ${ }^{26}$.

No último quartel do século $\mathrm{xx}$, coincidindo com a chegada da democracia, a crónica diversifica-se no estilo e na estética: elegante em Eduardo Prado Coelho, satírica em Vasco Pulido Valente ou Manuel António Pina, quotidiana em Cardoso Pires e António Lobo Antunes, denunciadora em Fernando Dacosta e Miguel Sousa Tavares ${ }^{27}$. Hoje nenhum diário a dispensa e alguns fazem mesmo gala da diversidade de estilos e de cronistas, como o Público, que esta semana divulga repetidamente, numa página inteira, o conjunto dos seus cronistas e / ou colunistas ${ }^{28}$.

Qual os sentimentos palpitam no escritor-cronista? Lembra-os Mário de Carvalho nesta passagem:

o escritor cronista: perora sobre tudo numa olímpica omnisciência. Está convencido de que tem muita graça e de que influi profundamente nos destinos do país. Imagina os governantes a lê-lo e a dizerem às mulheres (ou aos maridos): «Tem graça! Olha que este rapaz tem carradas de razão, vou passar a fazer como ele diz...» [...] no entanto fica um pouco perplexo quando os amigos exclamam jovialmente: «Lá li a tua coisa no Diário Popular. Aquela dos rinocerontes, muito gira...» - quando ele tinha escrito umas considerações hábeis sobre chalés suíços no Diário de Notícias. ${ }^{29}$

3.2 Escritores e diários - em intriga e mexericos

3.2.1 Prémios e comendas recebidos e recusados - É Vergílio Ferreira quem, a 12 de Junho de 1979, dá notícia do seguinte:

Domingo, dia de Camões e da Pátria, fui pois condecorado [em Vila Real]. A propósito do Marão [eu e o Namora] fizemos as nossas considerações sobre o Torga. Havia a história da venera [vieira (nome

26. Fernando Venâncio, op. cit., p. 8.

27. Fernando Venâncio, op. cit., p. 13.

28. Público, 2.11.2004, p. 13

29. Fernando Venâncio, op. cit., p. 16. 
de peixe e sua concha) ou concha do romeiro especialmente o que se dirigia a Santiago de Compostela; insígnia ou medalha] que mais logicamente que a qualquer um de nós lhe devia ser atribuída a ele. Donde eu ia concluir que a recusara.

Antes, porém, de eu atacar o assunto, um parceiro, meu quase desconhecido, contou-me uma coisa espantosa. Contara-lha um tipo que presenciara o caso e dele falara mesmo num jornal [s.n.] omitindo, no entanto, o nome do protagonista, um certo escritor, autor de histórias edificantes sobre animais. O nosso homem é caçador. E andando um dia à caça, indignou-se com o cão que não lhe dava as voltas lá como ele queria. Então furioso, apontou a arma ao cão e estoirou-o com um tiro. É uma história exemplar que ele devia incluir numa edição dos seus contos. Fiquei sem fala varado de espanto. E indignação.

\section{[...]}

Mas a venera. Torga, portanto, tê-la-á recusado? O Jornal aludia a que ele se recusara a fazer o discurso na sessão solene «por motivos políticos». Políticos? Só se é por vivermos em democracia. Ora ao que consta, a coisa metia era o problema da condecoração. Pois quem mais do que ele estava destinado à comenda? E isto põe uma questão curiosa e dificílima de entender. Muita gente acha ridículo que um sujeito seja condecorado - e, ao que parece, Torga achou-o também. Mas todos julgam de louvar e invejar que se lhe meta no bolso o montante de um prémio. Ora a venera é uma coisa simbólica, muito mais consentânea com a espiritualidade da arte... Não senhor. $\mathrm{O}$ «bago» é que é. Custa-me a admitir que o Torga assim o pense. Porque teríamos, então, que estaria certo ter ele aceite das mãos «fascistas» do Augusto de Castro os trinta contos do Prémio Diário de Notícias; mas estaria errado aceitar o prémio simbólico da comenda das mãos democráticas de Eanes. Bons Deuses. E tive eu pejo em aceitar os cinquenta contos do Prémio Nacional de Literatura que o SNI ou coisa assim me queria dar. Aceitei a venera vencendo o ridículo que pela voz comum se me queria impor.

\subsection{Escritores e diários - desavindos ou de candeias às} avessas

3.3.1 $O$ esquecimento que dói e a presença que mata Miguel Torga, queixava-se já na juventude da vil tristeza, durante a vida, e do esquecimento, após a morte: 
Em vida é o calvário que sabemos: Camões a morrer de fome, [...] Herculano sem forças diante de tanto lodo, Camilo a cavar romances com a fome com que o povo cava as leiras [...] e Gomes Leal a servir de bolo em Lisboa. Depois da morte, é a descida solene ao esquecimento, com a eterna lápide, o discurso oficial $[\ldots]^{30}$

Mais tarde, as suas queixas seriam bem mais dolorosas, perante a expectativa da notícia da sua morte:

Informada da minha morte iminente pelos meios de comunicação social, toda a gente me olha espantada, como se eu fosse um ressuscitado. Alguns, mais afoitos, aproximam-se e chegam à fala. Como S. Tomé. Querem meter a mão na chaga e ver para crer. [...] nasci com a sina de esgotar todos os cálices de amargura. Até este de agonizar no palco do mundo a pedir lágrimas e a receber apupos e felicitações. ${ }^{31}$

3.3.2 O desapontamento perante a luz e a sombra Vergílio Ferreira tem dificuldade em aceitar o lugar que lhe é atribuído em vários lugares, entre eles, nos diários:

a) No dia 10 de Junho de 1977, dia de Camões e das Comunidades Portuguesas, celebrado na Guarda, a cidade da sua juventude, escreve:

Está o governo em peso e outras notabilidades a assistir. Levo o meu texto no bolso, estou desejoso de o despejar. Não pertenço ao mundo público. Leio enfim o texto, palmas frias, não me fiz ao a+causo intervalar elevando a tempo a voz em berro e suspendendome para a ovação. Da mesa da Presidência, só o Presidente da República veio ter comigo e meã apertou a mão dizendo-me: «maravilhosos». Depois foi a vez do Sena. E o Jorge de Sena fez a sua cena, Berrou gesticulou, invectivou. Foi aclamado em delírio.

Três dias depois, escreve:

Toda a imprensa falou das cerimónias da Guarda. O Jorge de Sena em primeiro plano com retrato e tudo. Eu, secundarizado,

30. Miguel Torga, Diário II, Coimbra, 1977, $4^{a}$ ed., p. 33.

31. Miguel Torga, Diário IX-XVI, Coimbra, 1995, p. 1590. 
como é da minha condição. E sem retrato. Houve mesmo um fundista do Dia que me chamou «escolástico», como se estivesse a falar para uma assembleia de letrados. E houve mesmo quem não mencionasse o meu nome, para simplificar. [...] Em todo o caso, várias pessoas, pouco sensíveis ao berro, felicitaram-me. A Maria Barroso, por exemplo. Já o marido, o Mário Soares, disse-me que «precisava primeiro de ler o meu texto». Mau agoiro. Deve-lhe ter cheirado a heresia. ${ }^{32}$

Também a 2 de Junho de 1979, escreve:

Ontem tive um telefonema da Presidência da República. [...] era para me dizerem que [...] me iria agraciar [a 10 de Junho] e ao Namora com a Ordem de S. Tiago, «que é prestigiadíssima». Fiquei embatucado e ainda não caí em mim. Onde é que eu me criei um destaque para isto? Sempre me imaginei num percurso marginal, invisível a quem passa pela estrada real. E, de súbito, isto. Já depois da revolução o meu nome e o do Namora foram dados como condecoráveis pelos jornais [s.n.]. Mas nunca mais se falou no caso e julguei pois que o caso esquecera. O Namora, eu compreendo, tem representatividade, tem «nome». Mas eu? Que é que eu sou em termos públicos? Sempre me sonhei um destino discreto, quase clandestino [...] E de repente. Vêm-me dizer que não. Sou «representativo», tenho uma significação pública..$^{33}$

3.4 Escritores e diários - cumplicidade, violência verbal e fuga à censura política

3.4.1 Mário Dionísio e a essência do Reo-Realismo (anos 30 / 40) - Há momentos em que os escritores, organizados ou não, lançam mão dos diários para se imporem, imporem a sua escola ou movimento, imporem a sua visão da sociedade e até da luta político-ideológico-estética que está para lá da sua produção artística. Pensamos em Mário Dionísio, «porta-voz mais consciente da

32. Vergílio Ferreira, Conta Corrente 2, 1977-1979, Lisboa, Bertrand, 1981, pp. 58-59. 33. Vergílio Ferreira, Conta Corrente 2, 1977-1979, Lisboa, Bertrand, 1981, p. 267. Poderá validamente consultar-se ainda uma outra passagem na página 158 , referida ao dia 20 de Janeiro de 1978. 
necessidade da preservação dos valores estéticos dentro do Neo-Realismo português» ${ }^{34}$ e na entrevista clássica, dada ao Primeiro de Janeiro, em 3 de Janeiro de 1945, onde defende o movimento da acusação de se afastar da dimensão artística. Afirma:

Os neo-realistas repelem vivamente a lenda do seu desinteresse pelos assuntos estéticos. [...] um neo-realista é como qualquer escritor, um homem que necessita da literatura e da arte como seu único meio possível de exprimir-se. O mesmo autor afirmava a 15 de Abril do mesmo ano, a $O$ Globo: Os valores estéticos são valores. São elementos sem os quais não existe arte. [...] Passar sem eles, no entanto, de modo nenhum. Os problemas técnicos da literatura e da arte preocupam grandemente os novos escritores, eles são, afinal, a sua ferramenta $[\ldots]$.

Lembremos que esta mensagem-defesa era bem necessária, pois seis anos antes (1939) Alves Redol, em epígrafe a Gaibéus, colocara afirmações polémicas e doutrinárias indo em sentido bem contrário ao escrever: «Este romance não retende ficar na literatura como obra de arte. Quer ser antes de tudo um documentário humano fixado no Ribatejo. Depois disso será o que os outros entenderem. $\gg^{35}$ Mesmo se ao Diário de Lisboa, em 31 de Janeiro de 1958, assim matizava tais afirmações:

Gaibéus e Fanga no período do Neo-realismo, em que o primado do social, valorizado por necessidade polémica - não se esqueça de que nos batíamos contra os partidários da arte pela arte - esbatia as determinações individuais, as particularidades psicológicas, os tipos, os caracteres, as paixões humanas. ${ }^{36}$

Também vale a pena lembrar que desde a denominação até ao conceito de Neo-Realismo as confusões e insatisfações iniciais eram grandes, como este historiador do movimento confessa:

34. Alexandre Pinheiro Torres, O Neo-Realismo Literário Português, Lisboa, Morais Editores, 1977, pp. 22-23.

35. Alexandre Pinheiro Torres, op. cit., p. 19.

36. Alexandre Pinheiro Torres, op. cit., p. 19. 
[...] as designações Novo Humanismo e Neo-Humanismo [...] só possuem sentido se encaradas como vocábulos polémicos com significado que [...] era fundamentalmente o de contestarem o e ultrapassarem a ideologia do Socialismo burguês. Novo Humanismo foi, como muitos outros, uma máscara eufemística para ludibriar a Censura ditatorial [...]; o Neo-Realismo nada mais era do que a expressão artístico-literária do Novo Humanismo. [...] a própria palavra Neo-Realismo era um remendo, uma improvisação, um termo que não agradava mesmo àqueles que tiveram de lançar recurso dele, na impossibilidade de usarem Realismo-Socialista. ${ }^{37}$

Até Vergílio Ferreira registará a 21 de Setembro de 1978 que «durante o salazarismo houve o surto neo-realista que após o 25 de Abril se disse publicamente ser a extensão estética do comunismo. Na realidade, não demos todos conta disso». ${ }^{38}$

3.4.2 Os neófitos e seus padrinhos em guerra - Outros casos há em que os escritores lançam mão dos diários para polemizarem entre si, em réplicas e tréplicas que por vezes cavam fundo nos leitores. Ficou célebre a refrega entre Vergílio Ferreira e Alexandre Pinheiro Torres ${ }^{39}$, no momento em que saia Rumor Branco de Almeida Faria, em 1962, prefaciado pelo primeiro e questionado pelo segundo que defendia a disciplina do neo-realismo perante a ruptura que a obra representava. Observemos a primeira intervençaõ de Pinheiro Torres e réplica de Vergílio Ferreira:

APT - Qualquer destas atitudes, à primeira vista revolucionárias, não tem, todavia, nem a revolução da originalidade [...] nem do aproveitamento ideal [...] Claro que em princípio concordo com todas as indisciplinas. Mas [...] o caminho da indisciplina pode coincidir com o da facilidade.

37. Alexandre Pinheiro Torres, op. cit., pp. 14-15.

38. Vergílio Ferreira, Conta Corrente 2, 1977-1979, Lisboa, Bertrand, 1981, p. 217.

39. Cf. Anabela Dinis Branco de Oliveira, «Nouveau Roman em Portugal - Máscaras políticas de uma recepção em Portugal», in Anais da UTAD, Revista de Letras, n. ${ }^{\circ} 2$, Dez, 1998, pp. 183-184. 
Como resposta, Vergílio Ferreira é bastante sarcástico e considera o seu opositor um «temeroso Inquisidor», lançando-lhe ataques pessoais fortes, como se vê

VF - [...] pelo menos como artista Alexandre Pinheiro Torres é um medíocre. Estranho mesmo que uma alma caridosa ainda lho não tivesse dito discretamente ao ouvido, evitando assim que eu lho dissesse aqui em público.

Ao que obtém resposta à letra:

Vergílio Ferreira vem empregar a velha rábula do crítico ser um artista falhado. [...] Claro que também não me surpreende que, depois de declara que não é crítico, emita juízos de valor, pelo menos em relação à minha obra poética.

3.4.3 Despiste da censura ou a fala do além-regime - Guidinha de Luís Stau Monteiro - Este autor, entre as formas a que recorreu para tourear aos homens do lápis azul, foi criar uma crónica, julgo que semanal no Diário de Lisboa, se não erro, assinada por uma menina, natural e residente na Lisboa profunda, e que, da sua cidade / país, falava no estilo que passamos a ilustrar:

Somos os Campeões internacionais da radiografia

Isto aqui nas Graça vai de vento em popa agora que a gente soube que somos o país do mundo em que se tiram mais radiografias sim porque a gente havia de ser o primeiro país do mundo em qualquer coisa o que a gente não esperava era que posse em radiografias de maneira que tivemos uma surpresa bestial mas é como diz o meu pai antes sermos os primeiros em radiografias do que sermos os últimos em tudo cá em casa assim que tivemos a notícia começámos a integrar-nos no ambiente como diz a minha prima Josefa que já se integrou num curso de enfermagem que ficou a meio de um curso de estenografia que ficou a um terço de um curso de artes gráficas que acabou porque o caixa fugiu com o capital coitadinha da minha prima Josefa que trabalha numa mercearia apesar de estar tão integrada em tanta coisa pois como eu ia dizendo a prima Josefa [...]

Guidinha 
3.5 Escritores e diários - consagração e reconhecimento

3.5.1 Ascensão à direcção do diário - Ferreira de Castro e Vitorino Nemésio

Ferreira de Castro chegou a pertencer aos quadros do jornal O Século, mas foi sobretudo conhecido no seu tempo como escritor, tendo atingido elevado reconhecimento.

Todavia, Vitorino Nemésio, que sempre teve uma considerável actividade jornalística, no momento de abandonar a carreira académica, em 1971, quer «regressar» ao jornalismo. Todavia, como escreve José Martins Garcia,

é-lhe devido, como intelectual de prestígio, um cargo mais condigno. Esteve à beira de assumir a direcção de O Século... mas o caso complicou-se e o nome de Nemésio não chegou a figurar no cabeçalho deste jornal. E chega o dia 24 de Abril de 1974. [...] a «liberdade» de Abril sumiu-se em 1975. A Nemésio [...] já não consentem que palestre na televisão. É no meio da barafunda politico-ideológica que o escritor assume a direcção de O Dia, em 11 de Dezembro de 1975. [...] demite-se em 25 de Outubro de 1976. Reinicia então uma fase de intensa colaboração em jornais de Lisboa e do Porto.

3.5.2 A despedida póstuma - Do lado dos diários, como receptores de apoio ou suporte por parte dos escritores, podemos anotar a notícia da sua morte, que em alguns casos pode dar origem a cadernos inteiros de opiniões estudos e divulgação de elementos da sua obra. Exemplo disto foi o que aconteceu com o Público, no dia 10 de Julho passado, que dedicou as 31 páginas do Suplemento Mil Folhas a Sophia de Mello Breyner Andersen.

No caso de Jorge de Sena, é Vergílio Ferreira que regista o eco da sua morte, a 4 de Junho de 1978, nos jornais diários: «Ontem morreu o Jorge de Sena. [...] a imprensa deu grande relevo à notícia, vários intelectuais salientaram a grandeza do Sena. $\gg^{40}$ 
3.6 Escritores e diários - uma relação atípica

3.6.1 Como se sente um escritor perante a presença de um texto seu num exame nacional de Português ou de Literatura? Ouvimos dizer a Agustina Bessa Luís ser isso uma honra, visto serem os alunos educados desde a Antiguidade através de textos e se um dos seus for um deles, isso é para ela honroso. Para Torga, ver-se nos diários do dia 9 de Fevereiro de 1991, por na véspera cento e oito mil alunos terem feito a prova de acesso à Universidade deixa-o perplexo:

Quando escrevi o texto em causa, estava longe de imaginar que ele viria a ser motivo de mortificação académica. Em Portugal, a apetência literária morre na escola. Poucos mestres se empenham em ensinar os alunos a gostar de um autor. Que o diga Camões. Oxalá que, entre tantos jovens que me leram neste dia compulsivamente, alguns deles passem a ler-me voluntariamente, não por conta de qualquer júri ou computador, mas por real prazer, e descubram que um escritor não é dentro da pátria um inimigo público embuçado, mas uma prestável voz fraterna. ${ }^{41}$

\section{PARA CONCLUIR}

A presença dos escritores nos diários apresentará sempre uma razão intrínseca, ligada à própria natureza formativa que a informação transporta consigo: informar é também formar. Ora a formação para a qualidade de vida implica a arte e os artistas, como afirma Lilian Katz, investigadora americana da Universidade Illinois: "o segredo para ajudar a desenvolver [...] as capacidades, o mais possível, de maneira a aprender a viver plenamente é a arte [...]. Não se pode viver uma vida plena sem arte, ela dá-nos textura e forma $[\ldots] » .^{42}$

Diríamos, ainda, que, por estas formas comunicativas de expressão e de cidadania, registadas nos jornais diários, passam facetas várias da alma humana, desenhadas, discursivamente, por aqueles mesmos que a plasmam, tão artisticamente, nas suas obras - os escritores.

41. Miguel Torga, Diário IX-XVI, Coimbra, 1995, p. 1607.

42. Lilian Katz, «Entrevista», Público, 2.11.2004, p. 30. 


\section{REFERÊNCIAS BIBLIOGRÁFICAS}

Barreto, António, «Entrevista», Público, 1.11.2004.

BARros, João de e MurTa, Guerreiro, Como se devem ler os Escritores Modernos, Lisboa, Liv. Sá da Costa, s/d.

BolÉo, Manuel de Paiva, Para um maior rendimento do trabalho intelectual, Coimbra, Edição do Autor, 1952.

Campagne, E. M., Dicionário Universal de Educação e Ensino, trad. Camilo Castelo Branco, Porto e Braga, Liv. Internacional Ernesto Chardon e Eugénio Chardon, 1873.

Correia, João da Silva, Educação do Pensar Imaginativo e do Pensar Lógico, Coimbra, Imprensa da Universidade, 1924.

Ferreira, Vergílio, Conta Corrente 2, 1977-1979, Lisboa, Bertrand, 1981.

Garcia, José Martins, Vitorino Nemésio, Lisboa, Vega, 1988.

GarretT, Almeida, Viagens na Minha Terra, «Mas ainda espero melhor todavia, porque o povo, o povo povo, está são; os corruptos somos nós, os que cuidamos saber e ignoramos tudo», in http://www.bibvirt.futuro.usp.br/textos/autores/almeidagarret/viagensnaminhaterra/viagens_texto.html

Guerra, Abel, Elementos de Composição Literária, Porto, Livraria Apostolado da Imprensa, 1966, $6^{\text {a }}$ ed.

HugO, Victor, «Fonction du poète», in Littérature Française, XIX siècle, Lagarde et Michard, s/d.

KaTz, Lilian, «Entrevista», Público, 2.11.2004.

Lima, Maria de Lourdes Costa Lima dos Santos, Intelectuais Portugueses na Primeira Metade de Oitocentos, Lisboa, Presença, 1988. 
Oliveira, Anabela Dinis Branco de Oliveira, «Nouveau Roman em Portugal - Máscaras políticas de uma recepção em Portugal», in Anais da UTAD, Revista de Letras, n. ${ }^{\circ}$ 2, Dez, 1998, pp. 183184.

ReI, José Esteves, A Escola e o Ensino das Linguas, Porto, Porto Editora, 1998.

Saraiva, António José e LOPES, Óscar, História da Literatura Portuguesa, Porto, Porto Editora, 1976, 9a ed.

Saraiva, António José, «As duas literaturas portuguesas», Comércio do Porto, 28, 1960.

Saraiva, António José, Iniciação na Literatura Portuguesa, Lisboa, Gradiva, 1994.

Tengarrinha, José, História da Imprensa Periódica Portuguesa, Lisboa Portugália Editora, 1965.

Thibaudet, Histoire de la littérature française, apud, Dalcídio Jurandir, «Eça de Queiróz, repórter», in Livro do Centenário de Eça de Queiroz, Lúcia Miguel Pereira e Câmara Reys (orgs.), Lisboa e Rio, Edições Dois Mundos, Livros do Brasil e Livros de Portugal, 1945.

Torga, Miguel, Diário II, Coimbra, Edição do autor, 1977, 4ª ed.

Torga, Miguel, Diário (IX-XVI), Coimbra, 1995.

Torres, Alexandre Pinheiro, O Neo-Realismo Literário Português, Lisboa, Morais Editores, 1977.

Venncio, Fernando, Crónica Jornalística. Século XX, Antologia, Braga, Círculo de Leitores, 2004.

Verest, Jules, Manuel de Littérature. Principes - Faits Généraux - Lois, Bruxelles, Desclée, De Brouwer, Bruges, 1939, 14e ed. 